\title{
Genetic diversity and virulence pattern in field populations of Pyricularia grisea from rice cultivar Metica-1 ${ }^{(1)}$
}

\author{
Marta Cristina Filippi( ${ }^{(2)}$, Anne Sitarama Prabhu(2), Leila Garcês de Araújo(2) \\ and Josias Correa de Faria(2)
}

\begin{abstract}
Rice blast is a major yield constraint of the irrigated rice in the State of Tocantins, Brazil. The objective of this investigation was to study the phenotypic and genetic diversity within the pathogen population of Pyricularia grisea in samples collected from four individual farms of rice cultivar Metica-1, under epidemic conditions of leaf blast. A set of 87 isolates was tested on 32 rice genotypes including eight international differentials. Considering $80 \%$ similarity in virulence, two groups comprising a total of 81 isolates were recognized, independently of the farms from which they were collected. Eighty percent of the isolates pertained to pathotype ID-14, indicating high cultivar specificity and narrow diversity of virulence in the sample population. The virulence in pathogen population on rice cultivars BR-IRGA 409 and Rio Formoso was low. Analysis of P. grisea isolates using rep-PCR with two primer sequences from Pot 2 generated fingerprint profiles of one to nine bands. Cluster analysis revealed the occurrence of six fingerprint groups with similarities ranging from 0.09 to 1 . There was no straight relationship between virulence of the isolates based on reaction pattern on 32 genotypes and grouping based on Pot 2 rep-PCR analysis of $P$. grisea isolates collected from 'Metica-1'.
\end{abstract}

Index terms: Oryza sativa, pathotypes, rice blast, pathogenicity.

\section{Diversidade genética e padrão de virulência em populações de Pyricularia grisea provenientes da cultivar de arroz Metica-1}

\begin{abstract}
Resumo - A brusone é um dos fatores limitantes para a produção de arroz de várzea no Estado do Tocantins. A diversidade fenotípica e genética em população de Pyricularia grisea foi estudada, em amostras coletadas em quatro lavouras da cultivar Metica-1, sob condições de epidemias de brusone nas folhas. Foram testados 87 isolados em 32 genótipos, incluindo oito diferenciadoras internacionais. Considerando $80 \%$ de similaridade em virulência, dois grupos compostos por 81 isolados foram identificados, independentemente das lavouras onde foram coletados. Oitenta por cento dos isolados pertencem ao patótipo ID-14, indicando alta especificidade da cultivar e a diversidade estreita em virulência na população estudada. A virulência da população do patógeno nas cultivares comerciais BR-IRGA 409 e Rio Formoso foi baixa. A análise de isolados de $P$. grisea utilizando rep-PCR com dois primers Pot 2 gerou de uma a nove bandas. A análise de agrupamento revelou a ocorrência de seis grupos ou linhagens com similaridade variando de 0,09 a 1 . Não houve uma relação clara entre a virulência dos isolados dos 32 genótipos e o agrupamento baseado na análise usando rep-PCR de Pot 2 de isolados de P. grisea coletados na cultivar Metica-1.
\end{abstract}

Termos para indexação: Oryza sativa, patótipo, brusone, patogenicidade.

\footnotetext{
(1) Accepted for publication on August 5, 2002.

(2) Embrapa-Centro Nacional de Pesquisa de Arroz e Feijão, Caixa Postal 179, CEP 75375-000 Santo Antônio de Goiás, GO. E-mail: cristinafilippi@aol.com, prabhu@cnpaf.embrapa.br, leilag@cnpaf.embrapa.br, josias@cnpaf.embrapa.br
}

\section{Introduction}

Rice blast disease caused by Pyricularia grisea (Cooke) Saccardo [= Magnaporthe grisea (Hebert) Barr] is the major yield constraint in irrigated rice in the State of Tocantins, where cultivar Metica-1 is cultivated annually in extensive contiguous areas 
since 1984. Because of yield potential, 'Metica-1' continues to occupy more than $40 \%$ of the area planted. High input technology, including heavy doses of $\mathrm{N}$ fertilizer, herbicides, fungicides and insecticides, is used to maximize grain yield. The net profits are diminishing due to high cost of production inputs, causing serious concern to the farmers. Disease resistance constitutes a major component in the rice blast management and the research efforts are underway to develop resistant cultivars.

The study leading to determine the virulence diversity of field populations from a widely grown cultivar is important for blast resistance breeding. Rice blast fungus is composed of pathotypes or physiologic races with distinct virulence characteristics. These pathotypes are identified based on reaction type on a set of eight standard international differentials (Atkins et al., 1967). In Brazil and in many other countries, a great number of physiologic races have been reported to occur indicating the changes in virulence frequencies (Bonman et al., 1987; Ribeiro \& Terres, 1987; Urashima \& Isogawa, 1990; Correa-Victoria \& Zeigler, 1993; Filippi et al., 1999). Although genetic and phenotypic mutations from avirulence to virulence are common on susceptible cultivars, they are not apparent because of host susceptibility.

As information about the virulence and the genetic diversity of the isolates is available, their value and potential use increases. The characterization of genetic diversity in populations of $P$. grisea is being carried out with the employment of molecular techniques. Distinct DNA fingerprint groups or lineages were identified using MGR586 as a probe (Levy et al., 1991; Zeigler et al., 1995; Filippi et al., 1999). Because of difficulties in large scale use of RFLP analysis, rep-PCR technique with two primer sequences from Pot 2 has been developed. Comparison of groupings of isolates based on Pot2 rep-PCR and those obtained using MGR586 showed a close correspondence (George et al., 1998).

The objective of this investigation was to study the phenotypic and genetic diversity within the pathogen population of $P$. grisea in samples collected from four farms of rice cultivar Metica-1, under epidemic conditions of leaf blast.

\section{Material and Methods}

During 1996/97 rice growing season, isolates of $P$. grisea were collected from four individual 'Metica-1' farms, two of them from Lagoa da Confusão (I and IV) and two from the Rio Formoso project (II and III), approximately $200 \mathrm{~km}$ apart one from other, in the State of Tocantins. Single conidial isolates were established from sporulating lesions and stock cultures were maintained on sterilized filterpaper disks (Prabhu \& Filippi, 2001). A total of 87 isolates, 22, 25, 18 and 22 from Farms I, II, III and IV, respectively, were utilized to study the virulence and genetic diversity. They were tested on 32 rice genotypes, including 18 irrigated rice cultivars (IR-50, TKM-6, Bluebelle, Basmati-370, BL-1, Tetep, Maratelli, Kasube, Yochiro Mochi, Labelli, Metica-1, CICA-9, CICA-8, BR-IRGA 409, Aliança, Colombia-1, Rio Formoso, and IR-5), eight standard international differentials (Dular, Kanto 51, NP125, Raminad Str 3, Usen, Zenith, Caloro and Sha-tia-tsao), five near isogenic lines of CO 39 (C 101 LAC, C 101 A 51, C 104 PKT, C 101 PKT, C 101 TTP 4L 23) and CO 39.

The test material was planted in plastic trays $(15 \times 30 \times 10 \mathrm{~cm})$ containing $3 \mathrm{~kg}$ of soil fertilized with NPK ( $5 \mathrm{~g}$ of 5-30-15 $+\mathrm{Zn}$ and $3 \mathrm{~g}$ of ammonium sulfate). For each isolate, two trays were planted, each with 16 genotypes in rows of $5.0 \mathrm{~cm}$ in length and 10 to 12 plants per row. Twenty two-day-old plants were inoculated by spraying with aqueous spore suspension $\left(3 \times 10^{5}\right.$ conidia $\left./ \mathrm{mL}\right)$ on the leaves, until run-off, with an atomizer connected to an air compressor. The inoculated plants were incubated in plastic moist chamber in dark to induce and maintain dew on the plants for a period of 24 hours in dark. The disease reaction was assessed nine days after inoculation, following the visual rating scale of 0 to 3 , as incompatible, and 4 to 9 as compatible reactions (International Rice Research Institute, 1988).

The inoculation tests were repeated whenever the reactions were ambiguous and found necessary. International pathotype identification was based on the eight international differentials (Atkins et al., 1967). The virulence frequency of isolates was based on total number of compatible reactions on 32 test genotypes. A binary matrix was created from phenotypic virulence analysis by assigning 1 to compatible reaction and 0 to incompatible 
reaction on test varieties for constructing a matrix of similarity between all pairs of isolates, according to the coefficient of Jaccard (Clifford \& Stephenson, 1975). The phenogram of the isolates was constructed based on the matrix of similarity using unweighted pair groups with the arithmetic UPGMA method by program of the NTSYS-pc version 2.0/1997.

The molecular characterization of $P$. grisea isolates was done employing the DNA-fingerprinting protocol described by George et al. (1998). DNA extraction was performed utilizing the modified method of Raeder \& Broda (1985). Isolates were grown on culture medium (10 $\mathrm{g}$ dextrose supplemented with $2 \mathrm{~g}$ yeast extract per liter) in erlenmeyer flasks for four days without agitation, followed by 10 days with constant agitation in dark, at room temperature. One or two mycelial paper discs were transferred to erlenmeyer flasks containing $150 \mathrm{~mL}$ of culture medium.

The harvested mycelia were freeze-dried, lyophilized and macerated in liquid nitrogen. About $300 \mathrm{mg}$ of powdered mycelia was suspended in $700 \mu \mathrm{L}$ of extraction buffer (50 mM Tris-HCl, pH 8.0; 50 mM EDTA; $3 \%$ sodium dodecyl sulfate, wt/vol and $1 \%$ of mercaptoethanol) at $65^{\circ} \mathrm{C}$, for at least one hour. The cellular proteins were precipitated with $30 \mu \mathrm{L}$ of potassium acetate $\mathrm{pH}$ 5.2. DNA was precipitated in $200 \mu \mathrm{L}$ of cold isopropanol, washed with $70 \%$ ethanol, dried under vacuum and resuspended in TE buffer $(10 \mathrm{mM}$ Tris- $\mathrm{HCl}$, pH $8.0 ; 1.0 \mathrm{mM}$ EDTA), containing $10 \mathrm{mg} / \mathrm{mL}$ of RNase $\mathrm{A}$ and incubated at $37^{\circ} \mathrm{C}$ for 30 minutes. The DNA concentration was estimated by fluorometer and adjusted to $10 \mathrm{ng} / \mu \mathrm{L}$.

The oligonucleotide sequences were based on the primer sequence of the repetitive element Pot2 (EMBL accession Z33638), an inverted repeat transposon found in approximately 100 copies of the fungal genome $P$. grisea (Kachroo et al., 1994). The two primers (Pot2-1 5' CGGAAGCCCTAAAGCTGTTT 3' and Pot2-2 5' CCCTCATTCGTCACACGTTC 3') were designed from each end of Pot 2 in opposite orientation such that the 3 'ends were directed outward from each element. The oligonucleotide sequences were synthesized by Universidade Federal de Curitiba, Brazil.

DNA amplification reactions were performed, as described by George et al. (1998), with little modification in the procedure. Each $25 \mu \mathrm{L}$ reaction contained $50 \mathrm{ng}$ DNA, $2.5 \mu \mathrm{L} 10 \mathrm{X}$ buffer reaction $(200 \mathrm{mM}$ Tris- $\mathrm{HCl}$,
$\mathrm{pH} 8.4$ and $500 \mathrm{mM}$ of $\mathrm{KCl}), 2.0 \mu \mathrm{L} 50 \mathrm{mM} \mathrm{MgCl} 2 ; 0.5 \mu \mathrm{L}$ dNTP (10 mM each dATP, dGTP, dCTP and dTTP); $1.25 \mu \mathrm{L}$ each of the two primers $(100 \mathrm{mM}) ; 1.5$ units Taq polymerase, overlaid with $50 \mu \mathrm{L}$ mineral oil to prevent evaporation. The enzymatic amplification was performed in a thermocycler (M.J. Research, Inc.), programmed for 40 cycles. Each cycle was composed of 15 seconds, at $94^{\circ} \mathrm{C}$ (DNA denaturation); 30 seconds, at $35^{\circ} \mathrm{C}$ (pairing of the primer) and one minute at $72^{\circ} \mathrm{C}$ (extension of the primers). After 40 cycles, an extra extension step was performed for seven minutes at $72^{\circ} \mathrm{C}$.

Amplification products were separated by gel electrophoresis on $1.4 \%$ agarose gel in TBE buffer $(90 \mathrm{mM}$ Tris-borate and $2 \mathrm{mM}$ EDTA) containing $10 \mathrm{mg}$ of ethidium bromide. DNA bands were photographed under ultraviolet light, utilizing the photo documentation system, Eagle Eye II (Stratagene).

The fingerprinting patterns were analyzed based on the presence (1) or absence (0) of each band. The data were analyzed using the program NTSYS-pc version 2.0/ 1997. Genetic distances were calculated by the coefficient of similarity of Jaccard. The matrix of genetic distances was used for analysis and grouping the isolates based on the phenogram constructed by the method of UPGMA.

\section{Results and Discussion}

Out of 87 isolates of $P$. grisea, 70 pertained to pathotype ID-14 (Table 1). The occurrence of pathotype ID-14 on 'Metica-1' was earlier reported, in a sample collected in 1986 from Formoso do Araguaia (Filippi et al., 1999). Ten isolates were identified as pathotype ID-16, two as II-1 and one

Table 1. Race structure and frequency of Pyricularia grisea isolates collected from four commercial rice farms of 'Metica-1'.

\begin{tabular}{lccccc}
\hline Pathotype $^{(1)}$ & Farm I & Farm II & Farm III & Farm IV & $\begin{array}{c}\text { Total number } \\
\text { of isolates }\end{array}$ \\
\hline ID-14 & 21 & 19 & 13 & 17 & $70(80.5)$ \\
ID-16 & - & 3 & 5 & 2 & $10(11.5)$ \\
IB-33 & - & 1 & - & - & $1(1.1)$ \\
IB-45 & - & - & - & 1 & $1(1.1)$ \\
IB-46 & - & 1 & - & - & $1(1.1)$ \\
IG-2 & - & - & - & 1 & $1(1.1)$ \\
II-1 & 1 & - & - & 1 & $2(2.3)$ \\
IA-112 & - & 1 & - & - & $1(1.1)$ \\
\hline Total & 22 & 25 & 18 & 22 & 87 \\
\hline
\end{tabular}

${ }^{(1)}$ Pathotypes were determined based on eight standard international differentials. ${ }^{(2)}$ Values in parenthesis indicate percentages. 
each as IB-33, IB-45, IB-46, IG-2 and IA-112. They were obtained at random from different farms. The pathotypes IG-2 and IB-45, recovered from cultivar CICA-8 in rice blast nursery by Filippi et al. (1999), were found among the isolates collected from leaf lesions of Metica-1, in only one farm (IV).

The virulence frequency of isolates of $P$. grisea on 18 irrigated rice genotypes varied from $4 \%$ to $100 \%$ (Table 2). Differences in virulence pattern were not observed in isolates collected from different farms. All isolates collected were virulent on cultivar Metica-1. However, isolates retrieved from cultivar Metica-1 exhibited very low virulence frequency on commercial rice cultivars Rio Formoso, BR-IRGA 409 and Aliança, as well as the introduced ones, such as Tetep and Basmati-370. The virulence frequency of isolates to cultivars IR 50, IR 5 and Colombia-1 was high. Consistent incompatibility of isolates was shown by cultivar CICA-8, except one pathotype identified as IB-33 collected from Farm II. This was a unique pathotype collected from the field population of cultivar Metica-1 which has been shown to be virulent on 28 of the 32 test cultivars. The results are not in conformity with the earlier report (Filippi et al., 1999) that the isolates compatible to 'Metica-1' are incompatible to cultivar CICA-8 but the present

Table 2. Virulence frequency of Pyricularia grisea isolates collected from four commercial rice farms of 'Metica-1' on some irrigated rice genotypes ${ }^{(1)}$.

\begin{tabular}{lcccc}
\hline Cultivars & Farm I & Farm II & Farm III & Farm IV \\
\hline Metica-1 & $22(100)$ & $25(100)$ & $18(100)$ & $22(100)$ \\
Aliança & $0(0)$ & $1(4)$ & $0(0)$ & $0(0)$ \\
Rio Formoso & $1(4.5)$ & $1(4)$ & $2(11.1)$ & $2(9.1)$ \\
BR-IRGA 409 & $0(0)$ & $1(4)$ & $1(5.5)$ & $0(0)$ \\
CICA-8 & $0(0)$ & $1(4)$ & $0(0)$ & $0(0)$ \\
CICA-9 & $0(0)$ & $1(4)$ & $0(0)$ & $0(0)$ \\
Colombia-1 & $19(86)$ & $20(80)$ & $16(88.8)$ & $16(72.7)$ \\
Basmati-370 & $0(0)$ & $1(4)$ & $0(0)$ & $0(0)$ \\
IR 5 & $22(100)$ & $25(100)$ & $18(100)$ & $21(95.5)$ \\
IR 50 & $22(100)$ & $24(96)$ & $18(100)$ & $22(100)$ \\
Tetep & $0(0)$ & $1(4)$ & $0(0)$ & $0(0)$ \\
TKM & $4(18.2)$ & $7(28)$ & $4(22.2)$ & $4(18.2)$ \\
Bluebelle & $4(18.2)$ & $3(10.7)$ & $3(16.6)$ & $3(13.6)$ \\
BL 1 & $1(4.5)$ & $2(8)$ & $3(16.6)$ & $0(0)$ \\
Kasube & $5(22.7)$ & $10(40)$ & $2(11.1)$ & $0(0)$ \\
Labelle & $6(27.2)$ & $20(80)$ & $14(72.2)$ & $7(31.8)$ \\
Maratelli & $22(100)$ & $25(100)$ & $18(100)$ & $22(100)$ \\
Yachiro Mochi & $21(95.5)$ & $24(96)$ & $18(100)$ & $19(86.4)$ \\
\hline Total number of isolates & 22 & 25 & 18 & 22 \\
\hline & & &
\end{tabular}

Pesq. agropec. bras., Brasília, v. 37, n. 12, p. 1681-1688, dez. 2002 analysis showed that rare isolates occur in natural field population. This isolate was also virulent on cultivar Tetep, the broad spectrum resistance source used for breeding in different countries including Brazil. These results suggest the pre-existence of virulence genes in the pathogen population, indicating thereby that the resistance of newly released cultivars becomes ineffective over time. In studies on population dynamics of Phytophthora infestans, the virulence gene $\mathrm{R} 4$ was shown to be pre-existent even though the gene was never used by the potato breeders (Plank, 1982).

Virulent and avirulent isolates were detected in the sample population of P. grisea, to the known genes in the near isogenic lines of CO 39 (NIL's). All 87 isolates were virulent to genes $\mathrm{Pi}-3, \mathrm{Pi}-4 \mathrm{a}$ and $\mathrm{Pi}-4 \mathrm{~b}$ (Table 3). Isolates with virulence to isogenic lines C 101 LAC (Pi-1) and C 101 A 51 (Pi-2) were rare. Two isolates, one each from Farm II and Farm IV were virulent to genes Pi-1. Similarly, one isolate from Farm II and two isolates from Farm III were virulent to Pi-2. The pathotype IB-33 was found to be virulent on both $\mathrm{Pi}-1$ and $\mathrm{Pi}-2$. The incorporation of blast resistance genes $\mathrm{Pi}-1$ and $\mathrm{Pi}-2$ in the irrigated rice cultivars against the pathotype ID-14 is important but do not warrant stability because the virulence already exists in the field population, even though in low frequency. Pyramiding these two genes in one cultivar may possibly contribute to greater durability.

The similarities in phenotypic virulence on 32 rice genotypes are shown in phenogram (Figure 1). All isolates were associated at $48 \%$ Jaccard's similarity coefficient. At $80 \%$ similarity, two groups, comprising

Table 3. Virulence of Pyricularia grisea isolates collected from four commercial rice farms of 'Metica-1' on near isogenic lines of susceptible recurrent parent CO 39.

\begin{tabular}{lccccc}
\hline Isogenic lines & Resistance & \multicolumn{4}{c}{ Number of virulent isolates } \\
\cline { 3 - 6 } & gene & Farm I & Farm II & Farm III Farm IV \\
\hline C 101 LAC & Pi-1 & 0 & 1 & 0 & 1 \\
C 101 A 51 & Pi-2 & 0 & 1 & 2 & 0 \\
C 104 PKT & Pi-3 & 22 & 25 & 18 & 22 \\
C 101 PKT & Pi-4a & 22 & 25 & 18 & 22 \\
C 105 TTP4L23 & Pi-4b & 22 & 25 & 18 & 22 \\
CO 39 & & 22 & 25 & 18 & 22 \\
\hline Total number of isolates & & 22 & 25 & 18 & 22 \\
\hline
\end{tabular}




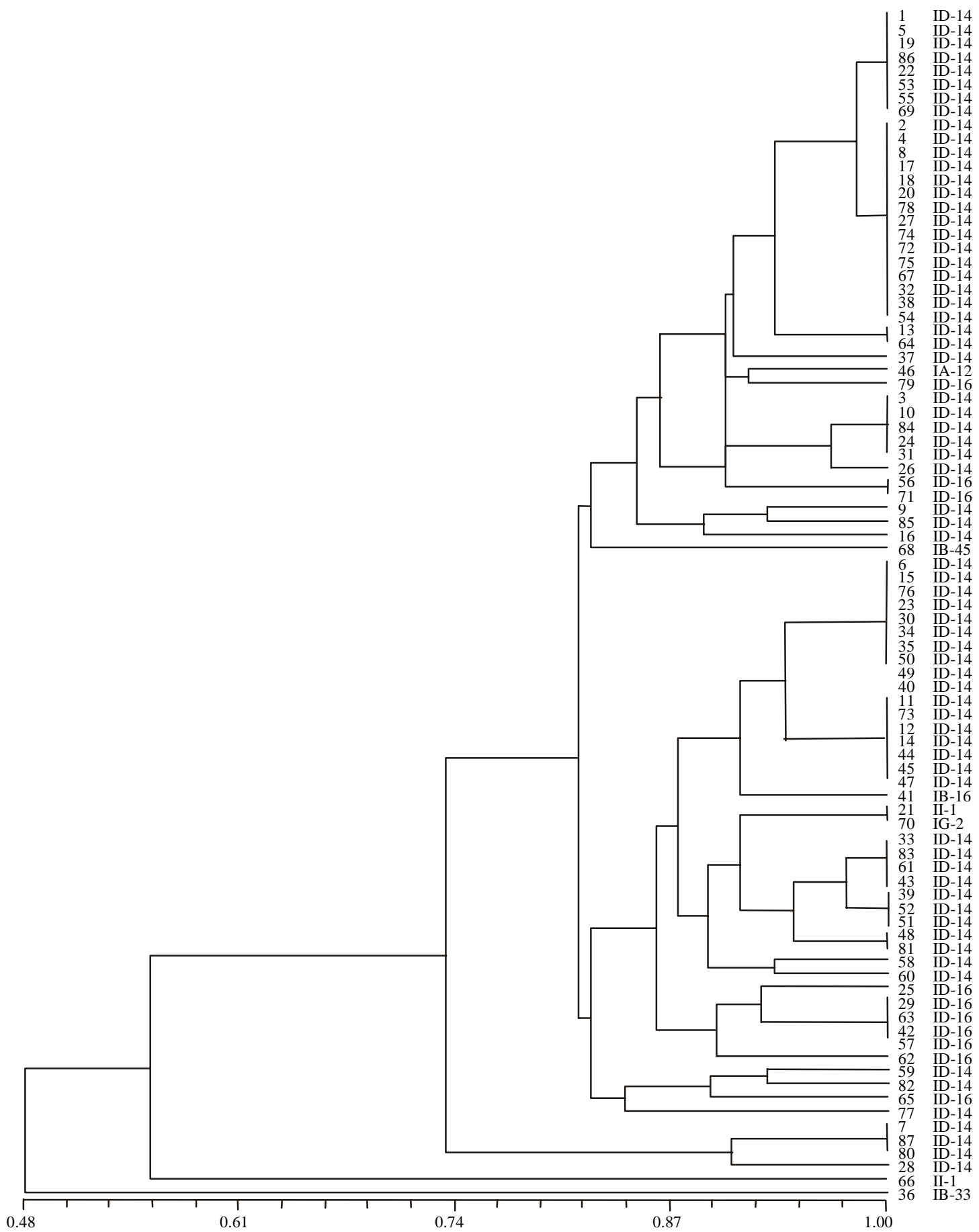

Figure 1. Phenogram of 87 Pyricularia grisea isolates (1-87) from rice cultivar Metica-1 constructed using UPGMA based an Jaccard's similarity coefficients; data from phenotypic virulence analysis; scale on bottom represents coefficients of similarity; pathotypes are indicated following the isolate numbers. 
a total of 81 isolates, were recognized. The third group with values of similarity coefficients ranging from 0.48 to 1.0 comprised six isolates. The pathotypes, IA-12, IB-45, IB-16, ID-16, IG-2, II-1, besides ID-14 were assigned to the groups I and II. The pathotypes IB-33 and II-1 of the group III exhibited wide dissimilarity from the rest of the isolates.

The rep-PCR fingerprint profiles of 19 of the 87 isolates tested, as an example, are shown in Figure 2. The isolates exhibited differences and similarities in banding pattern varying from one to nine fragments of $200 \mathrm{bp}$ to $1,300 \mathrm{bp}$ in length. The isolates 19 to 36 represent three different pathotypes, II-1 (21), ID-16 (25 and 29), IB-33 (36) besides ID-14. These isolates were collected from cultivar Metica-1 in two different farms (19 to 22 from Farm I and 23 to 36 from Farm II). Fourteen of them were assigned as being the same as that of reference isolate 19 (ID-14). However, isolates of the same pathotype, such as ID-14, had comparable number of bands with some degree of polymorphism. It was possible to distinguish the isolates representing pathotypes ID-14 from IB-33 (36) and ID-16 (25 and 29) and from one another. In each of these, four to six isolate specific fragments were used to distinguish from the isolates belonging to ID-14. Even though the isolates 25 and 29 were identified as ID-16, they showed different virulence pattern on NIL's.
The isolates could be clustered into six distinct groups, considering the coefficient of similarity ranging from 0.09 to 1.0 (Figure 3 ). The average similarities within a cluster were greater than the average similarities between the clusters. Some isolates identified as ID-14 exhibited less than 70\% similarity. The distribution of isolates within the phenogram was not in consensus with virulence pattern. However, the isolate ID-14 created a relatively closed group with coefficient values ranging from 0.66 to 1.0. The similarities within groups I and II, with the exception of one isolate, were more than 0.82 . The six lineages comprised more than one pathotype. The studies on genetic structure of isolates of P. grisea utilizing MGR-DNA fingerprinting showed that even though each isolate had unique fingerprint, they could be grouped into distinct lineages (Levy et al., 1991; Correa-Victoria \& Zeigler, 1993). A simple relationship between lineages and pathotypes was originally postulated but later studies showed diversity of virulence within lineages (Zeigler et al., 1995). The genetic analysis using rep-PCR cannot be used reliably to determine pathotypes of the fungus because there was no close correspondence between rep-PCR grouping and pathotypes. However, rep-PCR would serve as an important tool to differentiate genetically distinct

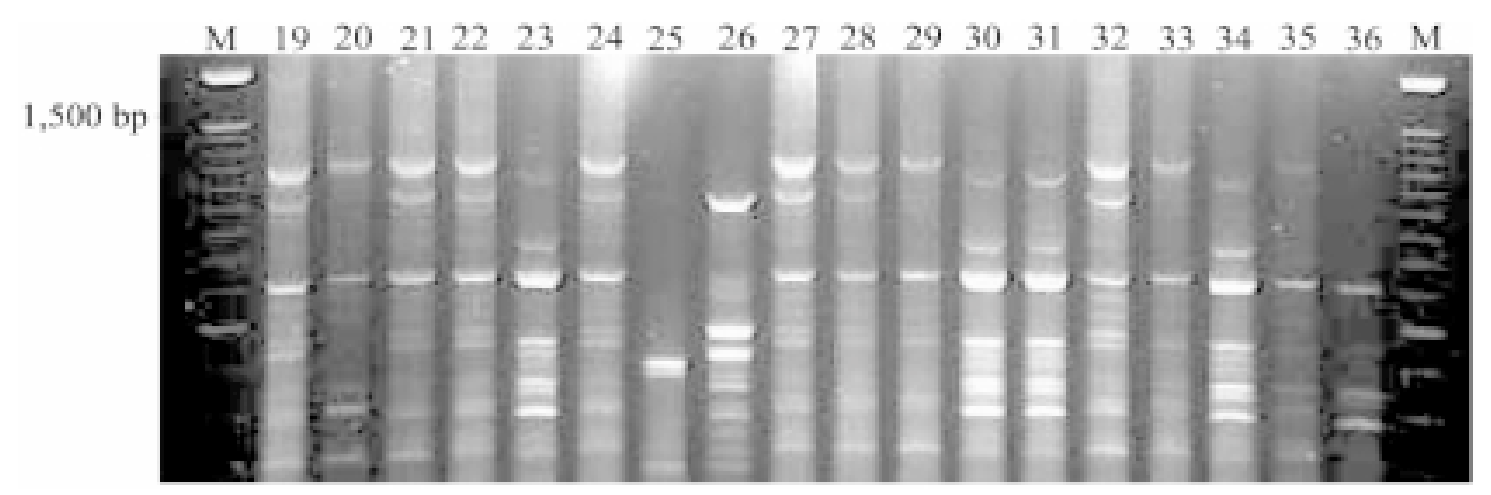

Figure 2. Analysis with Pot2 rep-PCR showing DNA fingerprint profiles of Pyricularia grisea isolates collected in four farms of cultivar Metica-1 in the State of Tocantins. M: Marker size Lambda 100 bp, Gibco BRL. Isolates numbers correspond to the numbers indicated in the phenogram. 


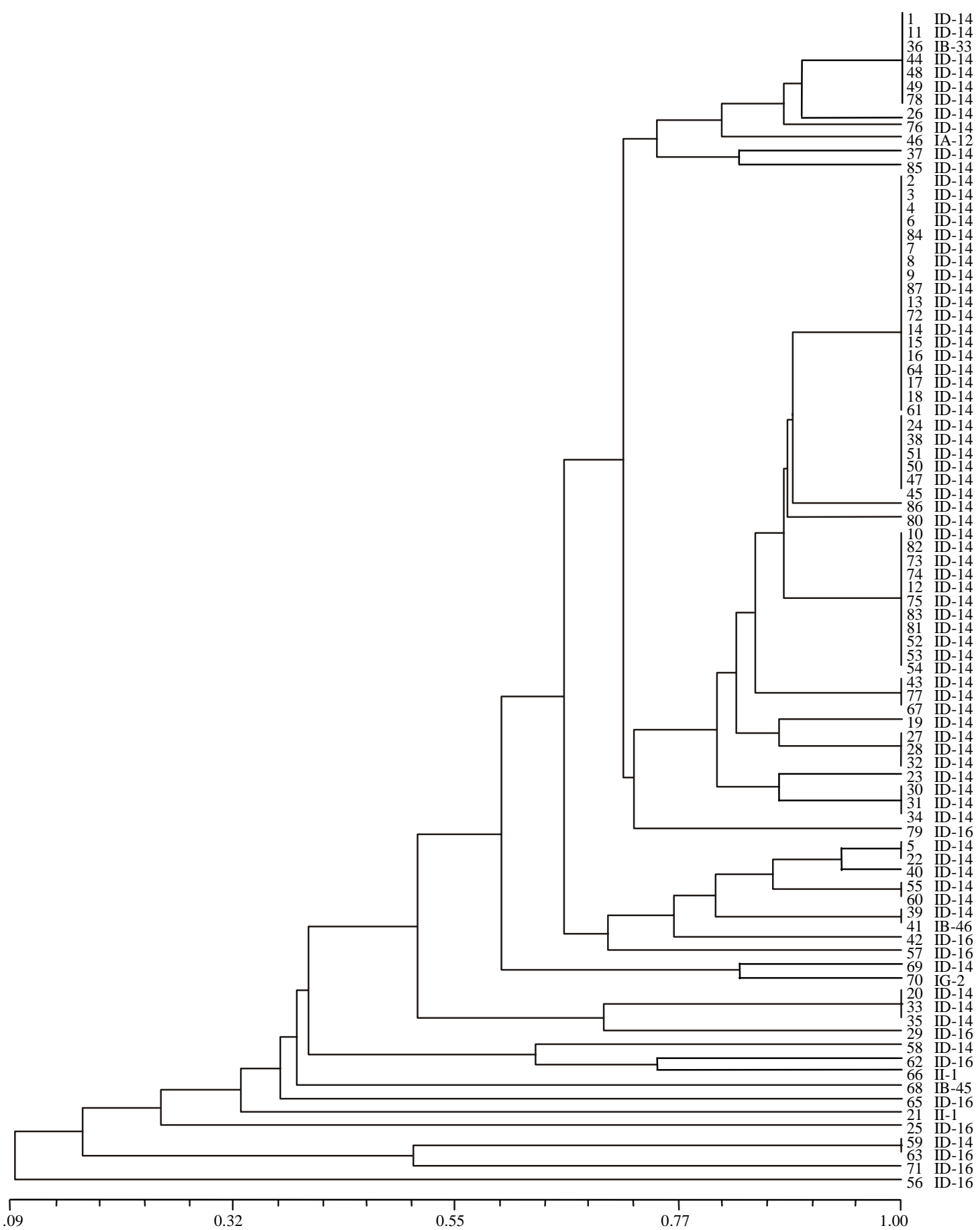

Figure 3. Phenogram of 87 Pyricularia grisea isolates (1-87) from rice cultivar Metica-1, constructed using UPGMA based an Jaccard's similarity coefficients; data from Pot 2 rep-PCR analysis; scale on bottom represents coefficients of similarity; pathotypes are indicated following the isolate numbers. 
isolates, which show ambiguous phenotypic reactions on differentials or distinctly different virulence pattern.

The diversity of virulence in the sample population was very narrow and exhibited restricted virulence spectrum. The narrow diversity of pathogen population can be ascribed to stabilizing selection (Plank, 1982) in favor of pathotypes such as ID-14 which have no unnecessary virulence genes beyond that required to infect cultivar Metica-1.

\section{Conclusions}

1. The diversity of virulence in the population of Pyricularia grisea collected from rice cultivar Metica-1 is narrow.

2. There are no differences in virulence pattern of Pyricularia grisea among isolates collected from different farms of cultivar Metica-1.

3. There is no straight relationship between the virulence of the isolates and grouping based on Pot 2 rep-PCR analysis.

\section{References}

ATKINS, J. G.; ROBERT, A. L.; ADAIR, C. R.; GOTO, K.; KOZAKA, T.; YANAGIDA, R.; YAMADA, M.; MATSUMOTO, S. An international set of rice varieties for differentiating races of Pyricularia oryzae. Phytopathology, St. Paul, v. 57, p. 297-301, 1967.

BONMAN, J. M.; VERGEL DE DIOS, T. I.; BANDONG, J. M.; LEE, E. J. Pathogenic variability of monoconidial isolates of Pyricularia oryzae in Korea and in the Philippines. Plant Disease, St. Paul, v. 71, p. 127130, 1987.

CLIFFORD, H. T.; STEPHENSON, W. An introduction to numerical classification. London: Academic, 1975. $229 \mathrm{p}$.

CORREA-VICTORIA, F. J.; ZEIGLER, R. S. Pathogenic variability in Pyricularia grisea at a rice blast "hot-spot" breeding site in Eastern Colombia. Plant Disease, St. Paul, v. 77, p. 1029-1035, 1993.
FILIPPI, M. C.; PRABHU, A. S.; LEVY, E. M. Differential compatibility of Pyricularia grisea isolates with some Brazilian irrigated rice cultivars. Fitopatologia Brasileira, Brasília, v. 24, p. 447-450, 1999.

GEORGE, M. L. C.; NELSON, R. J.; ZEIGLER, R. S.; LEUNG, H. Rapid population analysis of Magnaporthe grisea by using rep-PCR and endogenous repetitive DNA sequence. Phytopathology, St. Paul, v. 88, p. 223-228, 1998.

INTERNATIONAL RICE RESEARCH INSTITUTE (Los Baños, Philippiness). Standard evaluation system for rice. $3 \mathrm{rd}$ ed. $1988.54 \mathrm{p}$.

KACHROO, P.; LEONG, S. A.; CHATTOO, B. B. Pot2: an inverted repeat transposon from the rice blast fungus Magnaporthe grisea. Molecular and General Genetics, New York, v. 245, p. 339-348, 1994.

LEVY, M.; ROMÃO, J.; MARCHETTI, M. A.; HAMER, J. E. DNA fingerprinting with a dispersed repeated sequence resolves pathotype diversity in the rice blast fungus. Plant Cell, Rockville, v. 3, p. 95-102, 1991.

PLANK, J. E. van der. Host-pathogen interaction in plant disease. London: Academic, 1982. 207 p.

PRABHU, A. S.; FILIPPI, M. C. Graus de resistência à brusone e produtividade de cultivares melhoradas de arroz de terras altas. Pesquisa Agropecuária Brasileira, Brasília, v. 36, n. 12, p. 1453-1459, 2001.

RAEDER, U.; BRODA, P. Rapid preparation of DNA from filamentous fungi. Letters in Applied Microbiology, Oxford, v. 1, p. 17-20, 1985.

RIBEIRO, A. S.; TERRES, A. L. S. Variabilidade do fungo Pyricularia oryzae e sua relação com cultivares resistentes à brusone. Fitopatologia Brasileira, Brasília, v. 12, p. 316321, 1987.

URASHIMA, A. S.; ISOGAWA, Y. Identification of races of Pyricularia oryzae causing blast disease in variety IAC 4440 in Paraíba Valley-SP. Summa Phytopatologica, Piracicaba, v. 16, p. 243-247, 1990.

ZEIGLER, R. S.; COUC, L. X.; SCOTT, R. P.; BERNARDO, M. A.; CHEN, D. H.; VALENT, B.; NELSON, R. J. The relationship between lineage and virulence in Pyricularia grisea in the Philippines. Phytopatology, St. Paul, v. 85, p. 443-451, 1995. 